Asep Dadan Suganda

\title{
KONSEP WAKAF TUNAI
}

\begin{abstract}
Abstrak
Kata wakaf (jamaknya: awqaf) mengandung arti mencegah atau penahanan. Lebih jauh dapat dikatakan juga bahwa wakaf sebagai sesuatu yang substansi (wujud aktiva) dipertahankan, sementara hasil atau manfaatnya digunakan sesuai dengan keinginan dari orang yang menyerahkan (waqif) dengan proses legal sesuai dengan fungsi wakaf yang disebutkan dalam UU No.41 Tahun 2004 Pasal 5 yang menyatakan wakaf berfungsi untuk mewujudkan potensi dan manfaat ekonomis harta benda wakaf untuk kepentingan ibadah dan untuk memajukan kesejahteraan umum.

Wakaf tunai merupakan dana yang dihimpun oleh pengelola wakaf (nadzir) melalui penerbitan sertifikat wakaf tunai yang dibeli oleh masyarakat. Wakaf tunai dapat juga diartikan mewakafkan harta berupa uang atau surat berharga yang dikelola oleh institusi (perbankkan atau lembaga keuangan syari'ah) yang keuntungannya akan disedekahkan, dengan syarat modalnya tidak bisa dikurangi untuk sedekahnya, sedangkan dana wakaf yang terkumpul selanjutnya dapat digulirkan dan diinvestasikan oleh nadzir ke dalam berbagai sektor usaha yang halal dan produktif, sehingga keuntungannya dapat dimanfaatkan untuk pembangunan umat dan bangsa secara keseluruhan.

Komisi Fatwa Majelis Ulama Indonesia telah menetapkan fatwa berkenaan dengan wakaf tunai yang menyatakan bahwa (1) wakaf uang (cash wakaf atau waqf al-Nuqud) adalah wakaf yang dilakukan seseorang, kelompok orang, lembaga atau badan hukum dalam bentuk uang tunai, (2) termasuk ke dalam pengertian uang adalah surat-surat berharga, (3) wakaf uang hukumnya boleh (jawaz), (4) wakaf uang hanya boleh disalurkan dan digunakan untuk hal-hal yang dibolehkan secara syar'i, dan (5) nilai pokok wakaf uang harus dijamin kelestariannya, tidak boleh dijual, dihibahkan dan atau diwariskan.
\end{abstract}

Kata Kunci: Wakaf, Tunai.

\section{PENDAHULUAN}

Salah satu dari bentuk ibadah yang berkaitan dengan harta benda dengan tujuan untuk mendekatkan diri masing-masing pada Sang Pencipta adalah amalan wakaf. Wakaf sangat penting artinya bagi kehidupan sosial, ekonomi, kebudayaan dan keagamaan. Oleh karena itu, Islam meletakkan amalan wakaf sebagai salah satu macam ibadah yang amat menggembirakan. ${ }^{1}$

Perbincangan tentang wakaf sering kali diarahkan kepada wakaf benda yang bernilai tinggi seperti tanah, bangunan, pohon untuk diambil buahnya, sumur untuk diambil airnya dan sebagainya. Namun, seiring perkembangan zaman, tercipta suatu 
image atau persepsi tertentu mengenai wakaf tidak hanya terfokus pada benda yang bernilai tinggi, tetapi merambah juga kepada amalan mewakafkan uang tunai.

Tujuan dari penggalangan wakaf tunai dari masyarakat diantaranya untuk menciptakan kesadaran diantara orang-orang kaya atau berkecukupan untuk memikul beban tanggung jawab sosial terhadap masyarakat sekitar dengan harapan dapat terciptanya integrasi antara keamanan sosial, kedamaian dan meningkatkan kesejahteraan yang memiliki nilai keagamaan.

\section{PENGERTIAN}

Secara etimologi, wakaf berasal dari perkataan bahasa Arab "waqafa" yang artinya berhenti atau menahan. Menurut musnad Syafi'i, wakaf sama dengan tahbiis dan tasbiil yang artinya menahan: dikatakan waqaftu kadzaa artinya aku menahannya, tetapi tidaklah dikatakan auqaftuhu kecuali menurut dialek Tamim. Sedangkan artinya menurut istilah syara' ialah mempertahankan sejumlah harta yang dapat dimanfaatkan hasilnya, sedangkan pokoknya (modalnya) tetap utuh. ${ }^{2}$

Dalam terminologi hukum Islam, kata wakaf (jamaknya: awqaf) didefinisikan sebagai suatu tindakan penahanan dari penggunaan dan penyerahan asset dimana seseorang dapat memanfaatkan atau menggunakan hasilnya untuk tujuan amal, sepanjang barang tersebut masih ada. Wakaf juga memiliki arti menyerahkan hak milik yang tahan lama (zatnya) kepada seseorang atau nadzir (penjaga wakaf), baik berupa perorangan maupun badan pengelola dengan ketentuan bahwa hasil atau manfaatnya digunakan untuk hal-hal yang sesuai dengan syariat Islam. Sedangkan harta yang telah diwakafkan telah keluar dari hak milik yang mewakafkan, dan bukan pula menjadi hak milik nadzir, tetapi menjadi hak milik Allah SWT (dalam pengertian hak milik masyarakat umum).

Para ahli fikih berbeda pendapat dalam memberikan definisi wakaf, diantaranya seperti: Imam Hanafi yang mengartikan wakaf sebagai menahan materi benda (al'ain) milik wakif dan menyedekahkan atau mewakafkan manfaatnya kepada siapa pun yang diinginkan untuk tujuan kebajikan. Artinya bahwa kedudukan harta wakaf masih tetap tertahan atau terhenti di tangan wakif itu sendiri, dan wakif masih menjadi pemilik harta yang diwakafkannya, sedangkan perwakafannya hanya terjadi ke atas manfaat harta tersebut, bukan termasuk asset hartanya.

Sementara itu, Imam Syafi'i mengartikan wakaf dengan menahan harta yang bisa memberi manfaat serta kekal materi bendanya (al- 'ain) dengan cara memutuskan hak pengelolaan yang dimiliki oleh wakif untuk diserahkan kepada nadzir yang dibolehkan syariah. Golongan ini menysaratkan harta yang diwakafkan haruslah harta yang kekal materi bendanya (tidak mudah rusak atau musnah serta dapat diambil manfaatnya secara terus menerus).

Imam Maliki berpendapat bahwa arti dari wakaf adalah menjadikan manfaat suatu harta yang dimiliki (meskipun pemiliknya dengan cara sewa) untuk diberikan kepada orang yang berhak dengan satu akad (shighah) dalam jangka waktu tertentu sesuai dengan keinginan wakif. Artinya, wakaf tersebut hanya menentukan pemberian 
wakaf kepada orang atau tempat yang berhak saja. Sedangkan definisi wakaf menurut Imam Hanbali yaitu menahan asal harta (tanah) dan menyedekahkan manfaat yang dihasilkannya.

Dalam bahasa hukum kontemporer, wakaf berarti pemberian, dilakukan atas kehendak ahli waris, dengan satu niat memenuhi panggilan ketaqwaan. Wakaf juga dapat diartikan sebagai harta yang disumbangkan untuk berbagai tujuan kemanusiaan, sekali dalam selamanya, atau penyerahan asset tetap oleh seseorang sebagai bentuk manifestasi kepatuhan terhadap agama. ${ }^{3}$

Pengertian lainnya dapat ditemui dalam Undang-Undang Nomor 41 Tahun 2004, bahwa wakaf artinya suatu perbuatan hukum wakif untuk memisahkan dan /atau menyerahkan sebagian harta benda miliknya untuk dimanfaatkan selamanya atau untuk jangka waktu tertentu sesuai dengan kepentingannya guna keperluan ibadah dan /atau kesejahteraan umum menurut syariah. ${ }^{4}$

Dari beberapa definisi wakaf yang telah dipaparkan di atas, dapat disimpulkan bahwa wakaf bertujuan untuk memberikan manfaat atau faedah harta yang diwakafkan kepada orang yang berhak dan digunakan sesuai dengan ajaran syariah Islam. Dapat dikatakan juga bahwa wakaf sebagai sesuatu yang substansi (wujud aktiva) dipertahankan, sementara hasil atau manfaatnya digunakan sesuai dengan keinginan dari orang yang menyerahkan (waqif) dengan proses legal sesuai dengan fungsi wakaf yang disebutkan dalam UU No.41 Tahun 2004 Pasal 5 yang menyatakan wakaf berfungsi untuk mewujudkan potensi dan manfaat ekonomis harta benda wakaf untuk kepentingan ibadah dan untuk memajukan kesejahteraan umum.

\section{SEJARAH PERKEMBANGAN WAKAF}

Dalam perjalanannya, sejarah wakaf terus berkembang dan akan selalu berkembang mengikuti perkembangan zaman dengan berbagai inovasi-inovasi yang relevan. Sejarah peradaban Islam mencatat bahwa wakaf pertama kali dilakukan oleh Rasulullah SAW ketika membangun masjid Quba di Madinah. Wakaf kedua adalah mesjid Dar Al-Hijra di Madinah yang dibangun Rasulullah SAW. Namun, menurut versi yang berbeda, wakaf pertama adalah merupakan wakaf yang dilakukan Rasulullah SAW setelah mengambil alih kepemilikan tujuh buah kebun milik seorang Mukhairaiq (orang yahudi yang terbunuh ketika perang Uhud dan berpihak kepada Muslim). Peristiwa wakaf ini kemudian diikuti oleh Umar bin Khattab serta sahabatsahabat yang lain seperti Abu Bakar, Usman, Ali dan lainnya. Pada periode Abbasiyah, harta wakaf dan hasil-hasilnya tidak ditampung di Baitul Mal, namun dikelola oleh seorang Qadi yang selalu diawasi. Pada periode Abbasiyah tersebut kemudian dibentuk Baitul-Maal khusus untuk pengelolaan wakaf. ${ }^{5}$

Pada tahun 1922 telah terdapat wakaf di Indonesia yang berasal dari Islam, yaitu di Aceh, Gayo, Tapanuli, Jambi, Palembang, Bengkulu, Minahasa, Gorontalo (Sulawesi), Lombok, Jawa Timur, Jawa Tengah, dan Jawa Barat. Nama dan benda yang diwakafkan berbeda-beda, misalnya di Aceh disebut wakeuh, di Gayo disebut wokos, di Payakumbuh disebut $i b a h{ }^{6}$ 
Di Indonesia sendiri, wakaf telah diterima menjadi hukum adat bangsa Indonesia. Hal ini dapat dibuktikan dengan banyaknya benda wakaf, baik wakaf benda bergerak maupun benda tidak bergerak. Lebih jauh lagi, perhatian pemerintah terhadap wakaf begitu serius dengan diterbitkannya Undang-Undang No.41 Tahun 2004 tentang Wakaf dan PP No.42 Tahun 2006 tentang pelaksanaannya.

Selain dari perwakafan yang berasal dari Islam, terdapat pula perwakafan yang berasal dari hukum adat, misalnya di daerah Cibeo Banten terdapat tanah semacam tanah wakaf yang disebut Huma Serang yang digunakan untuk kepentingan umum dan untuk tempat upacara keagamaan. Di Bali juga terdapat semacam tanah wakaf yang digunakan sebagai tempat upacara keagamaan, biasanya diatas tanah tersebut didirikan Pura. ${ }^{7}$

Dalam hal wakaf tunai, Komisi Fatwa Majelis Ulama Indonesia pada tanggal 11 Mei 2002 telah menetapkan fatwa tentang wakaf tunai dan membolehkan pelaksanaanya. Seiring berjalannya waktu, wakaf telah mengalami perubahan paradigma terutama dalam hal pengelolaan wakaf yang ditujukan sebagai instrumen dalam upaya mensejahterakan masyarakat muslim. Oleh karena itu, pendekatan yang digunakan dalam pengelolaan wakaf ini menggunakan pendekatan bisnis dan manajemen (wakaf produktif).

Berkaitan dengan wakaf produktif, Achmad Junaidi (2005) menawarkan dua hal penting dalam paradigma baru wakaf, yaitu:

a. Asas Paradigma, yang meliputi; asas keabadian manfaat, asas pertanggungjawaban, asas profesionalistas manajemen, dan asas keadilan

b. Aspek Paradigma, meliputi; reformasi pemahaman mengenai wakaf, sistem manajemen kenadziran atau manajemen sumber daya insani dan sistem rekrutmen wakif. $^{8}$

Sepanjang sejarah Islam, wakaf telah memerankan peran yang sangat penting dalam mengembangkan kegiatan-kegiatan sosial, ekonomi dan kebudayaan masyarakat Islam. Dalam konteks kekinian, wakaf memiliki tiga ciri utama, antara lain seperti:

a. Pola managemen wakaf harus terintegrasi; dana wakaf dapat dialokasikan untuk program-program pemberdayaan dengan segala macam biaya yang tercapud id dalamnya

b. Asas kesejahteraan nadzir. Yaitu pekerjaan nadzir tidak lagi diposisikan sebagai pekerja sosial, tetapi sebagai profesional yang biasa hidup dengan layak dari profesi tersebut.

c. Asas transparansi dan tanggung jawab. Badan wakaf dan lembaga yang dibantunya harus melaporkan segala dana yang dikelola kepada umat setiap tahunnya. ${ }^{9}$ 


\section{DASAR HUKUM WAKAF}

Secara umum tidak terdapat ayat Al-Qur'an yang menerangkan konsep wakaf secara jelas. Dikarenakan wakaf adalah termasuk golongan infak di jalan Allah SWT (infaq $f i$ sabilillah), maka dasar yang digunakan oleh para ulama dalam menjelaskan dan menerangkan konsep wakaf ini berdasarkan pada keumuman ayat-ayat Al-Qur'an berkenaan dengan infaq. Diantaranya pada surat al-Baqarah ayat 267,

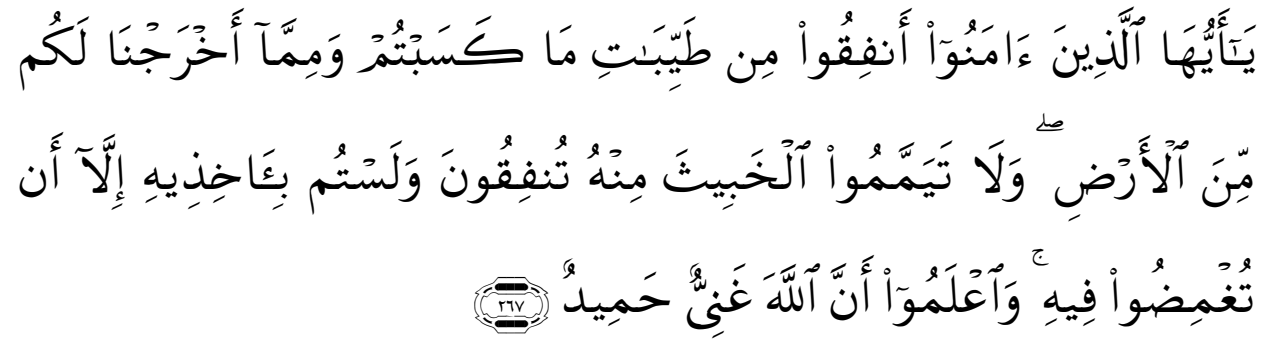

Artinya: "Hai orang-orang yang beriman, nafkahkanlah (di jalan Allah) sebagian dari hasil usahamu yang baik-baik dan sebagian dari apa yang kami keluarkan dari bumi untuk kamu. dan janganlah kamu memilih yang burukburuk lalu kamu menafkahkan daripadanya, padahal kamu sendiri tidak mau mengambilnya melainkan dengan memincingkan mata terhadapnya. dan Ketahuilah, bahwa Allah Maha Kaya lagi Maha Terpuji”.

Kemudian surat Ali Imran ayat 92:

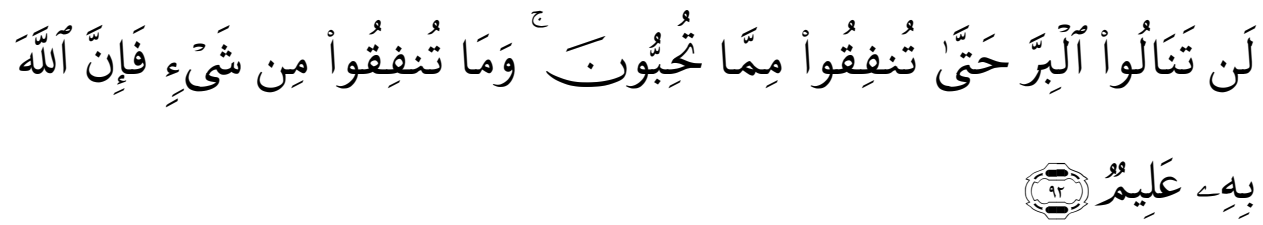

Artinya: "Kamu sekali-kali tidak sampai kepada kebajikan (yang sempurna), sebelum kamu menafkahkan sehahagian harta yang kamu cintai. dan apa saja yang kamu nafkahkan Maka Sesungguhnya Allah mengetahuinya”.

Serta pada surat al-Baqarah ayat 261:

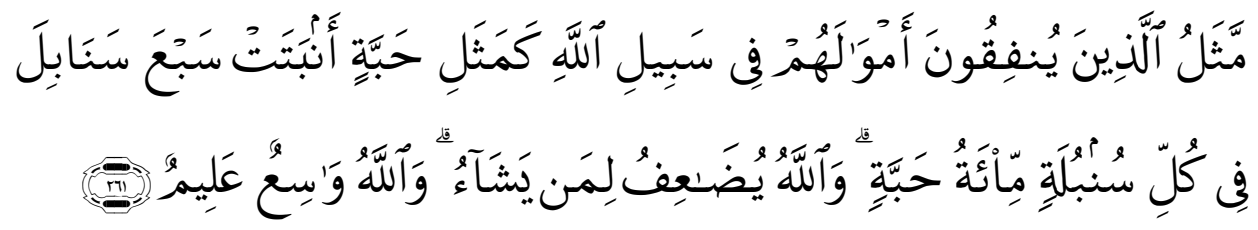

Artinya: "Perumpamaan (nafkah yang dikeluarkan oleh) orang-orang yang menafkahkan hartanya di jalan Allah ${ }^{10}$ adalah serupa dengan sebutir benih yang menumbuhkan tujuh bulir, pada tiap-tiap bulir seratus biji. Allah melipat gandakan (ganjaran) bagi siapa yang dia kehendaki. dan Allah Maha luas (karunia-Nya) lagi Maha Mengetahui”. 
Sedangkan hadist yang menjadi dasar hukum dan dalil wakaf adalah hadist yang diriwayatkan oleh Abdullah bin Umar, bahwa Umar bin Khatab mendapat sebidang tanah di Khaibar. Kemudian Umar bin Khatab menghadap Rasulullah SAW untuk memohon petunjuk tentang apa yang sepatutnya dilakukan terhadap tanah tersebut. Umar berkata kepada Rasulullah SAW, "Ya Rasulullah, saya mendapatkan sebidang tanah di Khaibar dan saya belum pernah mendapat harta lebih banyak dari tanah di Khaibar itu. Karena itu saya memohon petunjuk tentang apa yang sepatutnya saya lakukan pada tanah itu". Rasulullah SAW menjawab, "Jika engkau mau, tahanlah tanahmu itu dan engkau sedekahkan". Lalu Umar mensedekahkannya dan mensyaratkan bahwa tanah itu tidak boleh diwariskan. Umar juga menyalurkan hasil tanah itu untuk orang-orang fakir, ahli familinya, membebaskan budak, orangorang yang berjuang di jalan Allah, orang-orang yang kehabisan bekal dalam perjalanan dan tamu. Penguasa wakaf tunai sendiri, boleh makan dari hasil wakaf tersebut dalam batas-batas yang ma'ruf (biasa).

Selain dari al-Qur'an dan Hadist, para ulama telah bersepakat (ijma') menerima wakaf sebagai satu amal jariah yang disyariatkan dalam agama Islam. Tidak ada satu orang pun yang menafikan dan menolak praktik wakaf dalam Islam, karena wakaf telah menjadi amalan yang senantiasa dijalankan dan diamalkan sejak zaman Rasulullah SAW hingga sekarang.

Dalam konteks kenegaraan, pemerintah Republik Indonesia telah menetapkan undang-undang khusus mengatur tentang perwakafan di Indonesia, yaitu UndangUndang Nomor 41 Tahun 2004 tentang Wakaf. Untuk melengkapi undang-undang tersebut, pemerintah juga telah menetapkan Peraturan Pemerintah No. 42 Tahun 2006 tentang Pelaksanaan Undang-Undang No.41 Tahun 2004.

\section{RUKUN DAN SYARAT WAKAF}

Dalam wakaf terdapat rukun dan syarat yang harus dipenuhi agar amalan ini sesuai dengan aturan agama Islam. Yang termasuk ke dalam rukun wakaf dan syaratsyaratnya adalah:

\begin{tabular}{|c|l|l|}
\hline No. & \multicolumn{1}{|c|}{ Rukun } & \multicolumn{1}{c|}{ Syarat-Syarat } \\
\hline 1. & Al-Wakif & $\begin{array}{l}\text { Orang yang melakukan perbuatan wakaf. 1. } \\
\text { Hendaklah wakif memiliki secara penuh hartanya, 2. } \\
\text { Berakal dan dalam keadaan sehat rohaninya, tidak } \\
\text { dalam keadaan terpaksa atau dalam keadaan jiwa } \\
\text { yang tertekan, 3. Baligh, 4. Orang yang mampu } \\
\text { bertindak secara hukum (rasyid). }\end{array}$ \\
\hline 2. & Al-Mawquf & $\begin{array}{l}\text { Harta benda yang akan diwakafkan. 1. Harta harus } \\
\text { jelas wujudnya atau zatnya dan bersifat abadi } \\
\text { (barang berharga). 2. Diketahui jumlah/ kadarnya, 3. }\end{array}$ \\
\hline
\end{tabular}




\begin{tabular}{|l|l|l|}
\hline & & $\begin{array}{l}\text { Dimiliki penuh oleh orang yang berwakaf, 4. } \\
\text { Hartanya berdiri sendiri, tidak bercampur atau } \\
\text { melekat kepada harta lain. }\end{array}$ \\
\hline 3. & Al-Mawquf 'alaih & $\begin{array}{l}\text { Sasaran yang berhak menerima hasil atau manfaat } \\
\text { wakaf. Dapat dibagikan kepada wakaf khairy dan } \\
\text { wakaf dzurry. Wakaf Khairy adalah wakaf dimana } \\
\text { Al-Wakif tidak membatasi sasaran wakafnya untuk } \\
\text { pihak tertentu, tetapi untuk kepentingan umum. } \\
\text { Wakaf Dzurry adalah wakaf yang al-Wakif } \\
\text { membatasi sasaran wakafnya untuk pihak tertentu, } \\
\text { yaitu keluarga keturunannya. }\end{array}$ \\
\hline 4. & Shighah & $\begin{array}{l}\text { Pernyataan pemberian wakaf, baik secara lafadz, } \\
\text { tulisan maupun isyarat. 1. Ucapan mengandung } \\
\text { kata-kata yang menunjukan kekalnya amalan wakaf } \\
\text { tersebut (ta'bid), 2. Ucapan direalisasikan segera } \\
\text { (tanjiz), 3. Ucapan bersifat pasti, 4. Ucapan tersebut } \\
\text { tidak diikuti oleh syarat yang membatalkan amalan } \\
\text { wakaf. }\end{array}$ \\
\hline
\end{tabular}

Sumber: Andri Soemitra (2009) dengan modifikasi dari penulis

\section{KONSEP WAKAF TUNAI}

Kalangan ulama fikih masih kerap kali memperdebatkan apa hukumnya mewakafkan uang tunai. Ada yang membolehkan dan ada pula yang tidak membolehkan berwakaf dengan uang tunai. Hal ini disebabkan oleh cara yang biasa dipakai oleh masyarakat dalam mengembangkan harta wakaf berkisar hanya pada penyewaan harta wakaf, seperti tanah, gedung, rumah dan sejenisnya. Diantara alasan beberapa ulama tidak membolehkan berwakaf uang yaitu:

a. Uang bisa habis zatnya dalam sekali pakai. Uang hanya dimanfaatkan dengan membelanjakannya, sehingga bendanya lenyap. Padahal inti dari ajaran wakaf adalah pada kesinambungan hasil dari modal dasar yang tetap dan kekal. Oleh karena itu, ada persyaratan agar benda yang akan diwakafkan itu adalah benda yang tahan lama, tidak habis dipakai.

b. Uang seperti dirham dan dinar diciptakan sebgai alat ukur yang mudah, orang melakukan transaksi jual-beli, bukan untuk ditarik manfaatnya dengan mempersewakan zatnya.

Ibnu Taimiyah dalam al-Fatwa, meriwayatkan satu pendapat dari kalangan Hanafi yang membolehkan berwakaf ddalam bentuk uang dan hal yang sama pula dikatakan oleh Ibnu Quamah dalam bukunya al-Mughni. ${ }^{11}$ 
Jika meninjau kembali pengertian dari wakaf yang telah disebutkan di awal, kadangkala kita dirancukan dengan pengertian shadaqah dan hibah. Padahal antara wakaf, shadaqah dan hibah memiliki perbedaan-perbedaan penting, diantaranya yaitu:

\begin{tabular}{|c|l|ll|}
\hline No. & \multicolumn{1}{|c|}{ Wakaf } & \multicolumn{1}{|c|}{ Shadaqah/ Hibah } \\
\hline 1. & $\begin{array}{l}\text { Menyerahkan kepemilikan suatu } \\
\text { barang kepada orang lain }\end{array}$ & $\begin{array}{l}\text { Menyerahkan kepemilikan suatu barang } \\
\text { kepada pihak lain }\end{array}$ \\
\hline 2. & $\begin{array}{l}\text { Hak milik atas barang } \\
\text { dikembalikan kepada Allah } \\
\text { SWT. }\end{array}$ & $\begin{array}{l}\text { Hak milik atas barang diberikan kepada } \\
\text { penerima shadaqah/ hibah }\end{array}$ \\
\hline 3. & $\begin{array}{l}\text { Objek wakaf tidak boleh } \\
\text { diberikan atau dijual kepada } \\
\text { pihak lain }\end{array}$ & $\begin{array}{l}\text { Objek shadaqah/ hibah boleh diberikan } \\
\text { atau dijual kepada pihak lain }\end{array}$ & \\
\hline 4. & $\begin{array}{l}\text { Manfaat barang biasanya } \\
\text { dinikmati untuk kepentingan } \\
\text { sosial }\end{array}$ & $\begin{array}{l}\text { Manfaat barang dinikmati oleh } \\
\text { penerima shadaqah/ hibah }\end{array}$ & \\
\hline 5. & $\begin{array}{l}\text { Objek wakaf biasanya kekal/ } \\
\text { tahan lama zatnya }\end{array}$ & $\begin{array}{l}\text { Objek shadaqah/ hibah tidak harus } \\
\text { kekal zatnya. }\end{array}$ \\
\hline 6. & $\begin{array}{l}\text { Pengelolaan objek wakaf } \\
\text { diserahkan kepada administrator } \\
\text { yang disebut dengan nadzir/ } \\
\text { mutawalli }\end{array}$ & $\begin{array}{l}\text { Pengelolaan objek shadaqah/ hibah } \\
\text { diserahkan kepada si penerima }\end{array}$ \\
\hline
\end{tabular}

Sumber: Karim Business Consulting, 2003 dengan modifikasi dari penulis

Wakaf dengan menggunakan uang tunai membuka peluang yang unik bagi penciptaan investasi di bidang keagamaan, pendidikan, serta kegiatan sosial. Masyarakat yang berpenghasilan tinggi dapat dimanfaatkan melalui penukaran sertifikat wakaf tunai, sedangkan pendapatan yang diperoleh dari pengelolaan wakaf tunai tersebut dapat digunakan untuk berbagai kepentingan kemaslahatan umat.

Dari pengertian tersebut dapat dirumuskan bahwa wakaf tunai merupakan dana yang dihimpun oleh pengelola wakaf (nadzir) melalui penerbitan sertifikat wakaf tunai yang dibeli oleh masyarakat. Wakaf tunai dapat juga diartikan mewakafkan harta berupa uang atau surat berharga yang dikelola oleh institusi (perbankkan atau lembaga keuangan syari'ah) yang keuntungannya akan disedekahkan, dengan syarat modalnya tidak bisa dikurangi untuk sedekahnya, sedangkan dana wakaf yang terkumpul selanjutnya dapat digulirkan dan diinvestasikan oleh nadzir ke dalam berbagai sektor usaha yang halal dan produktif, sehingga keuntungannya dapat dimanfaatkan untuk pembangunan umat dan bangsa secara keseluruhan. ${ }^{12}$

Pengertian tersebut selaras dengan pendapat yang dikemukakan oleh Imam alZuhri yang menegaskan bahwa mewakafkan dinar hukumnya boleh, dengan cara 
menjadikan dinar tersebut sebagai modal usaha kemudian keuntungannya disalurkan pada orang atau sesuatu yang menjadi tujuan wakaf (mauquf 'alaih). ${ }^{13}$

Hal senada dikemukakan oleh Ulama Shafi'iyah yang berpendapat:

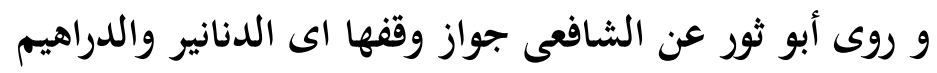

"Abu Thaur meriwayatkan dari al-Shafi'i tentang kebolehan wakaf dinar dan dirham (uang) ". 14

Dalam hal wakaf tunai, Komisi Fatwa Majelis Ulama Indonesia pada tanggal 11 Mei 2002 telah menetapkan fatwa berkenaan dengan wakaf tunai yang meliputi:

a. Wakaf uang (cash wakaf/ waqf al-Nuqud) adalah wakaf yang dilakukan seseorang, kelompok orang, lembaga atau badan hukum dalam bentuk uang tunai

b. Termasuk ke dalam pengertian uang adalah surat-surat berharga

c. Wakaf uang hukumnya jawaz (boleh)

d. Wakaf uang hanya boleh disalurkan dan digunakan untuk hal-hal yang dibolehkan secara syar'i

e. Nilai pokok wakaf uang harus dijamin kelestariannya, tidak boleh dijual, dihibahkan dan atau diwariskan.

Peruntukan harta benda wakaf diperuntukan bagi sarana dan kegiatan ibadah, sarana dan kegiatan pendidikan, sarana dan kegiatan kesehatan, bantuan kepada fakir miskin, anak terlantar, yatim piatu, beasiswa, kemajuan dan peningkatan ekonomi umat yang sesuai dengan syariah dan peraturan perundang-undangan.

\section{PENGELOLAAN WAKAF TUNAI}

Dalam pengelolaan wakaf tunai terdapat beberapa pihak yang dapat dijadikan sebagai pengelola harta wakaf, diantaranya yaitu bank syariah dan lembaga swasta.

\section{a. Wakaf Tunai Dikelola Oleh Bank Syariah}

Berikut adalah beberapa keuntungan yang didapatkan apabila dana wakaf tunai dikelola oleh bank syariah:

1. Jaringan kantor bank syariah.

2. Kemampuan bank syariah sebagai Fund Manager.

3. Pengalaman, jaringan informasi dan peta distribusi yang luas

4. Memiliki citra positif

Dengan memanfaatkan jaringan yang dimiliki bank syariah yang tersebar di berbagai daerah diharapkan dapat mengelola dana wakaf tunai baik sebagai penerima dana dari al-wakif maupun sebagai penyalur dana wakaf untuk dibagikan kepada al-mawquf' alaih. 
Didukung dengan kemampuan dan citra positif bank syariah sebagai fund manager, diharapkan dapat mengelola dana wakaf tunai dan berpotensi menambah nilai pokok uang yang diwakafkan setelah dialokasikan kepada usaha-usaha halal, sehingga semakin lama semakin bertambah. Imbasnya, dana yang disalurkan kepada yang berhak menerima pun semakin besar.

Untuk meminimalisir kerugian yang terjadi, pihak bank syariah dan fungsi pengelola dana wakaf tunai yang dilakukan oleh lembaga lain (misal Badan Wakaf Nasional) bekerja sama dengan lembaga penjamin.

Jika bank syariah sebagai nadzir penerima dan penyalur dana wakaf, maka skema yang dapat dijadikan alternatif adalah sebagai berikut:

\section{Gambar 1}

Skema Bank Syariah Sebagai Penerima dan Penyalur

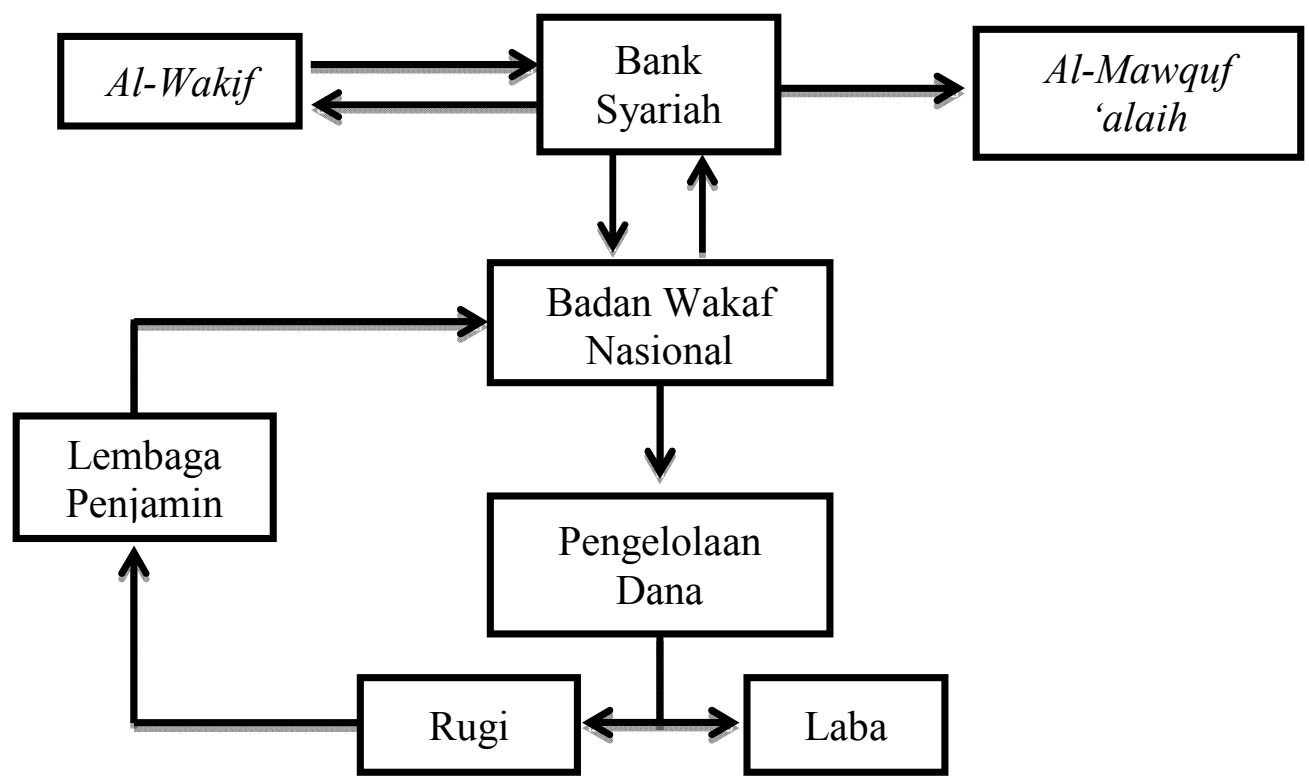

Sumber: Heri Sudarsono (2013)

\section{b. Wakaf Tunai Dikelola Oleh Lembaga Swasta}

Selain dikelola oleh bank syariah, dana wakaf tunai juga dapat dikelola oleh lembaga swasta. Misalnya lembaga swasta yang bergerak di bidang pendidikan. Keunggulan yang didapat apabila dana wakaf tunai dikelola oleh swasta antara lain adalah:

1. Sesuai dengan kebutuhan riil masyarakat

2. Ada kontrol langsung oleh masyarakat

3. Menumbuhkan solidaritas masyarakat 
Berikut adalah skema pengelolaan dana wakaf tunai yang dilaksanakan oleh pihak swasta yang bergerak di bidang pendidikan:

Gambar 2

Skema Lembaga Swasta Sebagai Penerima dan Penyalur

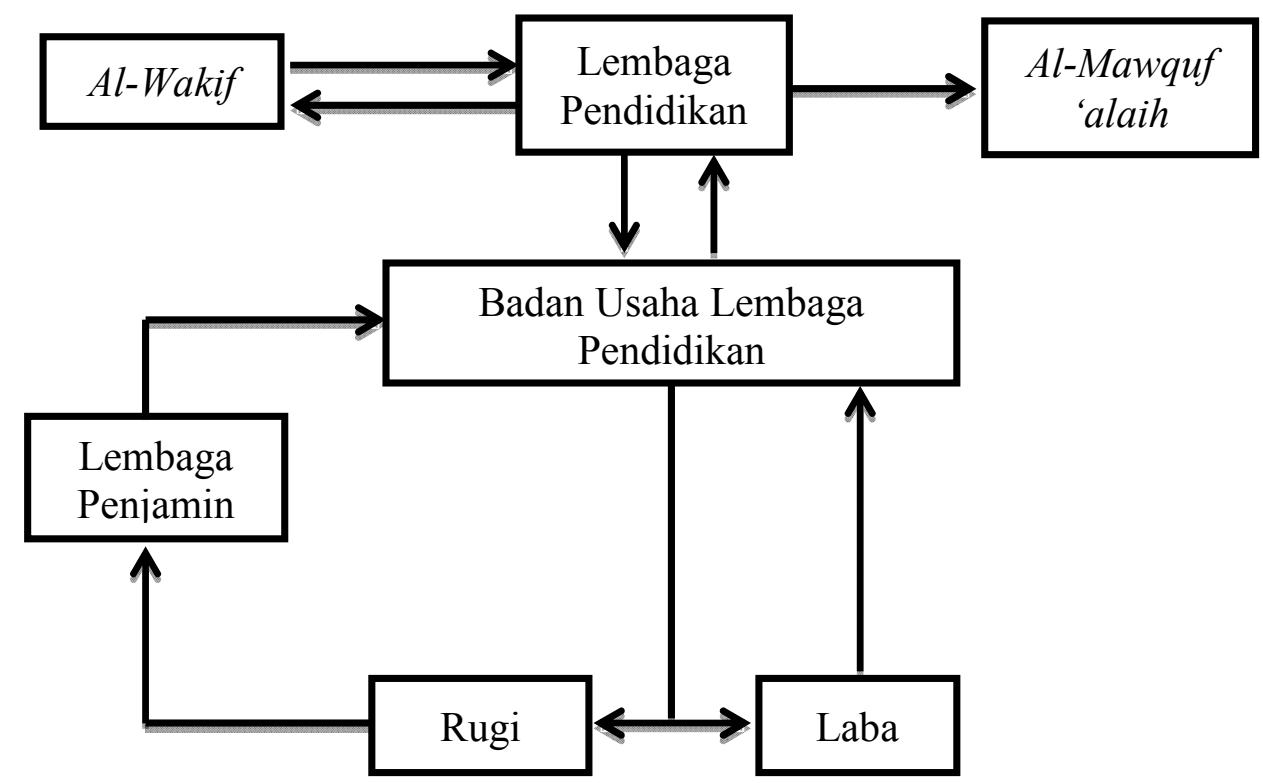

Sumber: Heri Sudarsono (2013)

Lembaga pendidikan swasta mengelola dana wakaf tunai yang diterimanya dengan sistem musyarakah atau mudharabah tanpa mengurangi nilai pokok (asset) wakaf. Setelah itu, keuntungan yang diterima dihitung berdasarkan atas sistem bagi hasil dan akan diterima oleh lembaga pendidikan sebagai keuntungan usaha dan diterima wakaf tunai sebagai tambahan asset. Dari keuntungan yang diperoleh, menjadikan asset wakaf semakin bertambah dan bisa digunakan membantu masyarakat dalam bentuk wakaf juga. 


\section{KESIMPULAN DAN SARAN}

\section{a. Kesimpulan}

Dari pemaparan berkenaan dengan konsep wakaf tunai diatas, dapat diambil kesimpulan bahwa:

1. Wakaf menurut Undang-Undang Nomor 41 Tahun 2004 adalah perbuatan hukum wakif untuk memisahkan dan/ atau menyerahkan sebagian harta benda miliknya untuk dimanfaatkan selamanya atau untuk jangka waktu tertentu sesuai dengan kepentingannya guna keperluan ibadah dan/ atau kesejahteraan umum menurut syariah.

2. Wakaf mempunyai peran dan fungsi penting dalam pembangunan masyarakat dan dalam pembangunan peradaban manusia, karena didalamnya terdapat kesinambungan manfaat pada donasi wakaf guna kepentingan ibadah dan untuk memajukan kesejahteraan umum.

3. Potensi dana wakaf tunai sangat besar, dapat diperuntukan bagi sarana dan kegiatan ibadah, sarana dan kegiatan pendidikan, sarana dan kegiatan kesehatan, bantuan kepada fakir miskin, anak terlantar, yatim piatu, beasiswa, kemajuan dan peningkatan ekonomi umat yang sesuai dengan syariah dan peraturan perundang-undangan.

\section{b. Saran}

Meskipun wakaf tunai telah dikenal diberbagai lapisan masyarakat Indonesia, penulis berusaha untuk memberikan beberapa saran agar ekspansi dan pertumbuhan wakaf tunai lebih maju lagi, diantara saran-saran tersebut adalah:

1. Lebih meningkatkan sosialisasi keberadaan wakaf tunai kepada masyarakat, bahwa masyarakat tidak perlu menunggu sampai jumlah tertentu hartanya untuk diwakafkan. Tetapi, wakaf dapat dilakukan dengan cash dan tidak harus dengan nominal yang banyak pula.

2. Untuk mendirikan lembaga wakaf tunai dapat dimulai dari lingkungan terkecil seperti; ta'mir masjid, pesantren dan sebagainya. Pendirian lembaga ini tidak harus menunggu kelompok atau institusi. Sekiranya sudah mampu mendirikannya, maka segera dirikanlah lembaga wakaf tunai.

3. Perlu diadakan koordinasi dengan lembaga zakat untuk menjalin kerjasama dan meningkatkan efektivitas kinerja antara lembaga terkait dengan tujuan untuk mensejahterakan masyarakat. 


\section{Catatan Akhir:}

${ }^{1}$ Ahmad Azhar Basyir, Hukum Islam Tentang Wakaf, Ijarah dan Syirkah, Bandung : PT. Al-Ma'arif, 1987, H. 7.

${ }^{2}$ Lihat Syekh Muhammad Abid As-Sindi, (2000), Musnad Syafi'i, Sinar Baru Algensindo, Bandung. H. 494.

${ }^{3}$ M.A. Mannan, 2001, Sertifikat Wakaf Tunai Sebuah Inovasi Instrumen Keuangan Islam, Ciber, PKTTI-UI

${ }^{4}$ Undang-Undang RI No.41 Tahun 2004 tentang Wakaf, Departemen Agama RI, Dirjen Bimas Islam dan Penyelenggaraan Haji, 2005, H.3.

${ }^{5}$ A. Malik al-Sayed, Social Ethics of Islam Vantage, (NY. USA, 1983).

6 Koesoemah Atmaja, (1922), Mohammedaensche vrome Stichtingen in Indie, Adipustaka S, Cramedia, Jakarta. Dalam Imam Suhadi, 2002, Wakaf Untuk Kesejahteraan Umat, Dana Bhakti Prima Yasa, Yogyakarta, H. 8.

${ }^{7}$ Imam Suhadi, 2002, Wakaf Untuk Kesejahteraan Umat, Dana Bhakti Prima Yasa, Yogyakarta, H. 39.

${ }^{8}$ Achmad Djunaidi dkk, Paradigma Baru Wakaf di Indonesia, Jakarta: Direktora Pengembangan Zakat dan Wakaf Depag RI, 2005. H. 63-85.

9 Muhammad Syafii Antonio, Pengantar Pengelolaan Wakaf Secara Produktif, dalam Achmad Djunaidi dan Thobieb al-Asyhar, Menuju Era Wakaf Produktif, Jakarta: Mumtaz Publishing, 2007, Cet. Ke-4, H. viii.

10 Pengertian menafkahkan harta di jalan Allah meliputi belanja untuk kepentingan jihad, pembangunan perguruan, rumah sakit, usaha penyelidikan ilmiah dan lain-lain.

${ }^{11}$ Biro Perbankan Syariah, (2001), Peranan Perbankan Syariah dalam Wakaf Tunai (Sebuah Kajian Konseptual), makalah seminar Wakaf Tunai-Inovasi Finansial Islam: Peluang dan Tantangan dalam Mewujudkan Kesejahteraan Sosial yang diselenggarakan oleh Program Pasca Sarjana Program Kajian Timur Tengah dan Islam, UI, H. 9.

12 Irfan Syauqi Beik, Wakaf Tunai dan Pengentasan Kemiskinan, (ICMI online, Halal Guide, September 2006).

${ }^{13}$ Abu Su'ud Muhammad, Risalah fi Jawazi Waqf al-Nuqud, (Bairut: Dar Ibn Hazm, 1997), $20-21$.

${ }^{14}$ al-Mawardi, Hawi al-Kabir, tahqiq Mahmud Matraji, Juz IX, (Bairut : Dar al-Fikr, 1994), 379.

\section{DAFTAR PUSTAKA}

\section{Al- Qur'an dan Terjemah}

A. Malik al-Sayed, Social Ethics of Islam Vantage, NY. USA, 1983.

Abu Su'ud Muhammad, Risalah fi Jawazi Waqf al-Nuqud, Bairut: Dar Ibn Hazm, 1997.

Achmad Djunaidi dkk, Paradigma Baru Wakaf di Indonesia, Jakarta: Direktora Pengembangan Zakat dan Wakaf Depag RI, 2005. 
Ahmad Azhar Basyir, Hukum Islam Tentang Wakaf, Ijarah dan Syirkah, Bandung: PT. Al-Ma'arif, 1987.

al-Mawardi, Hawi al-Kabir, tahqiq Mahmud Matraji, Juz IX, Bairut: Dar al-Fikr, 1994.

Andri Soemitra, Bank dan Lembaga Keuangan Syariah, Jakarta, Kencana Prenadamedia Group, 2012.

Biro Perbankan Syariah, Peranan Perbankan Syariah dalam Wakaf Tunai (Sebuah Kajian Konseptual), makalah seminar Wakaf Tunai-Inovasi Finansial Islam: Peluang dan Tantangan dalam Mewujudkan Kesejahteraan Sosial yang diselenggarakan oleh Program Pasca Sarjana Program Kajian Timur Tengah dan Islam, UI, 2001.

Heri Sudarsono, Bank dan Lembaga Keuangan Syariah Deskripsi dan Ilustrasi, Yogyakarta: Ekonisia, FEUII, 2012.

Imam Suhadi, Wakaf Untuk Kesejahteraan Umat, Dana Bhakti Prima Yasa, Yogyakarta, 2002.

Irfan Syauqi Beik, Wakaf Tunai dan Pengentasan Kemiskinan, ICMI online, Halal Guide, September 2006.

Koesoemah Atmaja, Mohammedaensche vrome Stichtingen in Indie, Adipustaka S, Cramedia, Jakarta. 1922. Dalam Imam Suhadi, Wakaf Untuk Kesejahteraan Umat, Dana Bhakti Prima Yasa, Yogyakarta, 2002.

M.A. Mannan, 2001, Sertifikat Wakaf Tunai Sebuah Inovasi Instrumen Keuangan Islam, Ciber, PKTTI-UI.

Muhammad Syafii Antonio, Pengantar Pengelolaan Wakaf Secara Produktif, dalam Achmad Djunaidi dan Thobieb al-Asyhar, Menuju Era Wakaf Produktif, Jakarta: Mumtaz Publishing, Cet. Ke-4, 2007.

Syekh Muhammad Abid As-Sindi, Musnad Syafi'i, Sinar Baru Algensindo, Bandung. 2000 .

Undang-Undang RI No.41 Tahun 2004 tentang Wakaf, Departemen Agama RI, Dirjen Bimas Islam dan Penyelenggaraan Haji, 2005 
Asep Dadan Suganda, Dosen pada Fakultas Syari'ah dan Ekonomi Islam IAIN Sultan Maulana Hasanuddin Banten. 